\title{
FUNCTIONAL INEQUALITIES IN MATRIX BANACH SPACES
}

\section{ZHIHUA WANG}

Abstract. Using the fixed point method, we prove the Hyers-Ulam stability of the following additive functional inequality and quadratic functional inequality

$$
\begin{gathered}
\|f(x+y)-f(x)-f(y)\| \leqslant\left\|f\left(\frac{x+y}{2}\right)-\frac{1}{2} f(x)-\frac{1}{2} f(y)\right\|, \\
\|f(x+y)+f(x-y)-2 f(x)-2 f(y)\| \\
\leqslant\left\|f\left(\frac{x+y}{2}\right)+f\left(\frac{x-y}{2}\right)-\frac{1}{2} f(x)-\frac{1}{2} f(y)\right\|
\end{gathered}
$$

in matrix Banach spaces, respectively.

Mathematics subject classification (2010): 47L25, 39B82, 39B72, 46L07. nach space.

Keywords and phrases: Fixed point method, functional inequality, Hyers-Ulam stability, matrix Ba-

\section{REFERENCES}

[1] T. AOKI, On the stability of the linear transformation in Banach spaces, J. Math. Soc. Japan 2 (1950), 64-66.

[2] J. B. DiAZ AND B. MARGOLIS, A fixed point theorem of the alternative for contractions on a generalized complete metric space, Bull. Amer. Math. Soc. 74 (1968), 305-309.

[3] W. FECHNER, Stability of a functional inequality associated with the Jordan-von Neumann functional equation, Aequationes Math. 71 (2006), 149-161.

[4] A. GILÁNYI, Eine zur Parallelogrammgleichung äquivalente Ungleichung, Aequationes Math. 62 (2001), 303-309.

[5] A. Gilányi, On a problem by K. Nikodem, Math. Ineq. Appl. 5 (2002), 707-710.

[6] P. GĂVRUTA, A generalization of the Hyers-Ulam-Rassias stability of approximately additive mappings, J. Math. Anal. Appl. 184 (1994), 431-436.

[7] D. H. Hyers, On the stability of the linear functional equation, Proc. Nat. Acad. Sci. U.S.A. 27 (1941), 222-224.

[8] S.-M. JUNG AND T.-S. KIM, A fixed point approach to the stability of the cubic functional equation, Bol. Soc. Mat. Mexicana (3), 12 (2006), 51-57.

[9] S.-M. JUnG, A fixed point approach to the stability of a Volterra integral equation, Fixed Point Theory Appl. 2007 (2007), Article ID 57064, 9 pages.

[10] H.-M. Kim, K.-W. JUn AND E. Son, Generalized Hyers-Ulam stability of quadratic functional inquality, Abst. Appl. Anal. 2013 (2013), Article ID 564923, 8 pages.

[11] J. LeE, C. PARK AND D. SHIN, An AQCQ-functional equation in Matrix normed spaces, Result. Math. 64 (2013), 305-318.

[12] J. Lee, D. Shin And C. PARK, Hyers-Ulam stability of functional equations in matrix normed spaces, J. Ineq. Appl. 2013 (2013), Article ID 22.

[13] C. PARK, Functional inequalities in non-Archimedean normed spaces, Acta Math. Sin. 31 (2015), 353-366.

[14] C. PARK, Y. S. CHO AND M.-H. HAN, Functional inequalities associated with Jordan-von Neumanntype additive functional equations, J. Ineq. Appl. Vol. 2007, Article ID 41820, 13 pages. 
[15] C. PARK, J. LeE AND D. ShIn, An AQCQ-functional equation in matrix Banach spaces, Adv. Diff. Equ. 2013 (2013), Article ID 146.

[16] C. PARK, J. LEE AND D. SHIN, Functional equations and inequalities in matrix paranormed spaces, J. Ineq. Appl. 2013 (2013), Article ID 547.

[17] C. PARK, D. Shin AND J. LeE, Fuzzy stability of functional inequalities in matrix fuzzy normed spaces, J. Ineq. Appl. 2013 (2013), Article ID 224.

[18] TH. M. Rassias, On the stability of the linear mapping in Banach spaces, Proc. Amer. Math. Soc. 72 (1978), 297-300.

[19] J. RÄTZ, On inequalities associated with the Jordan-von Neumann functional equation, Aequationes Math. 66 (2003), 191-200.

[20] S. M. Ulam, Problems in Modern Mathematics, Chapter VI, Science Editions, Wiley, New York, 1964. 